\title{
Conserving Pacific Island flying foxes
}

\author{
Amie Bräutigam and Thomas Elmqvist
}

Pacific Islanders, conservationists, and bat biologists are applauding the recent decision of the Parties to the Convention on International Trade in Endangered Species of Wild Fauna and Flora (CITES) to increase protection of flying foxes, or fruit bats, of the genera Acerodon and Pteropus from the adverse effects of international trade into US jurisdictions in the Pacific. This decision culminates efforts dating as far back as 1981 to control international trade in these species, which has decimated populations on many islands. It poses a challenge to US government authorities to institute wildlife trade controls in the Pacific and to Pacific Island governments, many of which are not yet CITES members, to develop effective measures to control exports of these and other species.

At their seventh biennial meeting held in Lausanne in October 1989, delegates of 91 of the current 105 CITES member states approved proposals submitted by the governments of Sweden and the United States to include seven species of flying foxes (Pteropus insularis, P. mariannus, P. molossinus, P. phaeocephalus, $P$. pilosus, $P$. samoensis, and $P$. tonganus) in CITES Appendix I (Table 1) and all six species of the genus Acerodon and the remaining 48 unlisted Pteropus species in CITES Appendix II. The Appendix I listing provides for a prohibition on international trade in those species that occur on the islands of the central and west Pacific, while the Appendix II listing provides for regulation of international shipments containing all other Pteropus and Acerodon species. The ongoing international trade in flying foxes serves a single consumer market in the United States, the islands of Guam and the Commonwealth of the Northern Marianas (CNMI), where these animals are a luxury food item.

Table 1. Pteropus species included in CITES Appendix I as of 18 January 1990

Pteropus insularis, Truk flying fox Pteropus mariannus, Mariana flying fox Pteropus molossinus, Pohnpei flying fox Pteropus phaeocephalus, Mortlock flying fox Pteropus pilosus, large Palau flying fox Pteropus samoensis, Samoan flying fox Pteropus tonganus, insular flying fox
International efforts to control the trade in flying foxes into Guam through the listing of several Pteropus species on CITES in 1981 had failed, largely because the trade at the time was primarily internal to the United States and, thus, outside of the purview of CITES. However, the evolution of the US Pacific Trust Territory into independent or quasi-independent states internationalized the trade and enhanced the capacity of CITES to contribute to the conservation of these species. In 1987, at the sixth biennial CITES meeting, the Parties approved the Appendix II listing of nine Pteropus species, including two ( $P$. pilosus and $P$. tokudae) believed to be already extinct. While this decision marked a certain degree of progress, continued failure by US authorities to implement mandated trade controls has meant that the recent Appendix I listing promises substantive international protection for these species for the first time. No fewer than 30,000 frozen flying fox carcasses have been imported into Guam alone in the years intervening between these two CITES listings.

\section{Biology, ecology and economic importance}

Although the genus Pteropus ranges from islands off the coast of East Africa to the oceanic islands of the South Pacific, including mainland South East Asia and Australia, its 


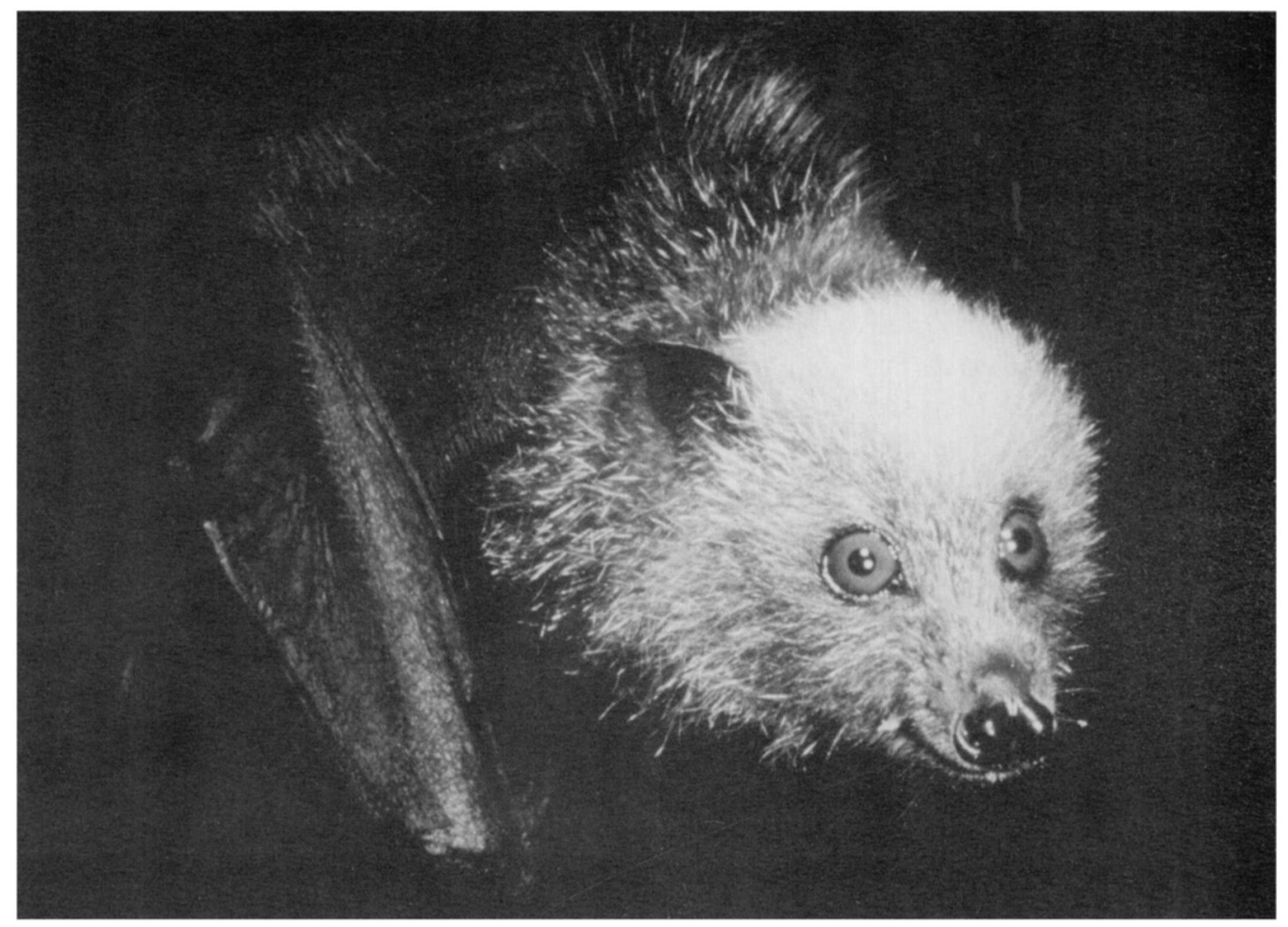

Samoan flying fox Pteropus samoensis (W.E. Rainey).

primary distribution is in the Pacific region: as many as 47 of the 57 species in the genus are found east of the Indian Ocean. In addition, Pteropus is primarily an island taxon, with 55 species (96.5 per cent) distributed entirely or at least partially on islands (Pierson and Rainey, in litt.). The geographic ranges of most species are extremely small: 35 species (61.4 per cent) are restricted to single islands or small island groups. Only seven species are found on continental land masses. The genus Acerodon is more limited in its distribution, being confined to the Philippines and central Indonesia (Musser et al., 1982); none of the six species occurs on continental land masses.

Flying foxes are long-lived, have a low reproductive rate for a small mammal, and, particularly on islands, have few natural predators. These and other factors, including complex social structures, specific food requirements, and a narrow range of potential roosting sites, render them vulnerable to a wide variety of threats associated with human intervention. These threats include over-hunting, introduction of exotic predators, destruction or alteration of habitat, such as tourism development and commercial logging, and, as has recently been documented, human disturbance unrelated to hunting, which may cause abandonment of roost sites (Wiles, 1988). When severely reduced by human action or natural catastrophes such as typhoons and epidemics, their populations are likely to be slow to recover.

Research in Africa, the Neotropics, and South East Asia, has documented the critical role that bats play in the pollination and seed dispersal of forest trees, many of them of economic importance to man (Marshall, 1985; Charles-Dominique, 1986; Thomas, 1987; Fujita and Tuttle, 1988). In the Pacific, distant, isolated oceanic islands have depauperate faunas 
and floras, but the level of endemism is very high (40-50 per cent for flowering plants on some islands), resulting in a high overall biodiversity in terms of unique species present. On these islands, flying foxes are often the only vertebrates capable of carrying largeseeded fruits and, in many instances, are the only pollinators available for many of the forest plants, particularly those that are nightblooming. The proportion of plant species [estimated at 30 per cent for Samoa, (Cox, unpubl.)] that are totally dependent on flying foxes for pollination or seed dispersal is therefore remarkably high compared with forests in continental areas. The extinction of flying foxes, as keystone pollinators and seed dispersers, would result in a cascade of linked extinctions of plants and other organisms dependent on them. Given the uniqueness of these communities, this signifies a tremendous loss of biodiversity.

Fujita and Tuttle (1988) have recorded at least 453 products of economic importance that derive from plant species relying, to varying extent, on bats for seed dispersal and pollination. The very popular durian fruit (Durio zibethinus) depends on bats for pollination, as does petai (Parkia speciosa and P. javanica). They estimate the monetary value of these and a third product (duku-Lansium domesticum) to exceed \$US4 million annually in Indonesia, while the Forest Institute of Malaysia estimates that annual sales of petai exceed \$US1 million in Peninsular Malaysia alone. Twelve tree species dependent on bats for dispersal are major timber species in Malaysia, one of the largest tropical timber exporters in the world. The kapok or silk-cotton tree (Ceiba pentandra) the fibre, bark and seeds of which are highly prized, is pollinated by a large number of bat species in Africa and South America (Baker and Harris, 1959) but pollinated solely by $P$. tonganus in Samoa.

\section{Importance as a dietary item}

Flying foxes are consumed as food by people in many areas of their range. Hunted for subsistence and medicinal purposes, they may have considerable local commercial value and are a luxury item on restaurant menus in some areas. In South East Asia, flying fox meat is valued as a remedy for asthma, kidney ailments, and fatigue, especially amongst people of Chinese origin (Fujita and Tuttle, 1988).

In the Pacific, flying foxes have been a regular component of the diet in some traditional subsistence communities and continue to be considered a delicacy in modern, more urbanized communities. Archaeological evidence indicates that the Chamorro people of the Marianas Islands have eaten flying foxes for over 1000 years (Lemke, 1986). Still considered a delicacy, they are served by Chamorros on social occasions such as village fiestas, weddings, christenings, and holiday celebrations (Wiles and Payne, 1986). As long as traditional hunting practices were used and tribal taboos and other cultural restrictions on the taking of flying foxes adhered to, this harvest seemed to have had little or no impact on flying fox populations (Lemke, 1986). However, with the introduction of firearms and a cash economy, and the resulting disintegration of traditional taboos (Falanruw, 1988), species' populations began to decline. Although the situation has become increasingly critical since World War II, overhunting had been identified as depleting flying fox populations as early as 1930 (Wiles and Payne, 1986).

\section{Commercial trade}

Elimination of all but a small number of flying foxes on Guam prompted the establishment of an import trade at least as early as 1970 (Wiles and Payne, 1986). Initially, imports originated in the adjacent islands of the Marianas (now the CNMI) and, subsequently, the Caroline Islands (including the Federated States of Micronesia and Palau). Protection from hunting of $P$. mariannus mariannus, indigenous to Guam and the southern islands of the CNMI, and $P$. tokudae (a Guam endemic now presumed extinct) by local legislation on Guam in 1973, followed by their listing on the Guam Endangered Species List in 1981 and, finally, the US Endangered Species list in 1984, further 


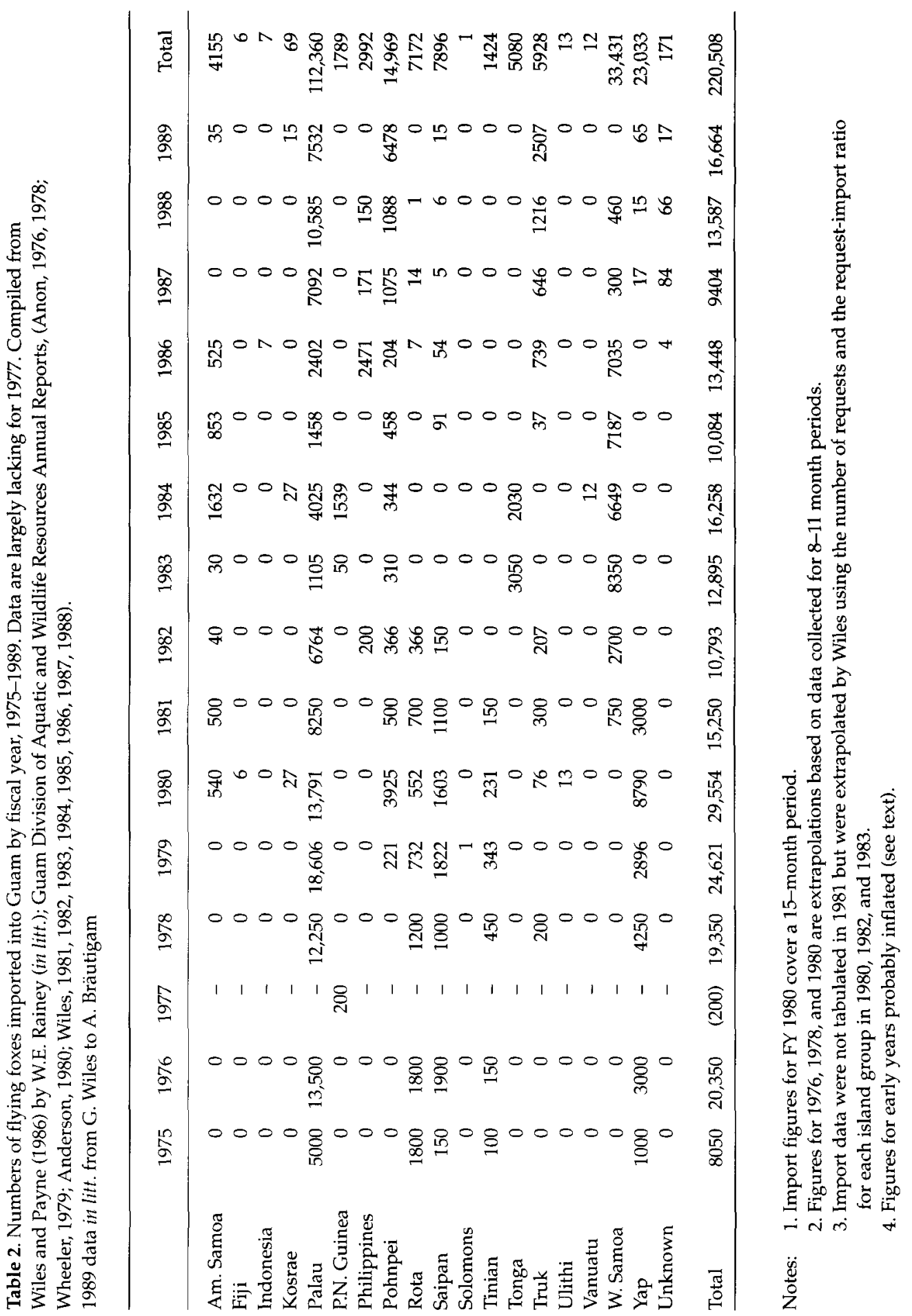


Table 3. Numbers of flying foxes requested for import into Guam by fiscal year, 1979-1989. Data derived from permit applications filed in expectation of bat imports. Compiled from Wiles and Payne (1986) by W.E. Rainey (in litt.); Guam Division of Aquatic and Wildlife Resources Annual Reports (Anon., 1976, 1978; Wheeler, 1979; Anderson 1980; Wiles, 1981, 1982, 1983, 1984, 1985, 1986, 1987, 1988). 1989 data in litt. from G. Wiles to A. Bräutigam

\begin{tabular}{|c|c|c|c|c|c|c|c|c|c|c|c|}
\hline & 1979 & $1980^{*}$ & 1981 & 1982 & 1983 & 1984 & 1985 & 1986 & 1987 & 1988 & 1989 \\
\hline Am. Samoa & 140 & 729 & 725 & 3480 & 200 & 21312 & 10600 & 1505 & 225 & 0 & 0 \\
\hline Australia & 0 & 0 & 0 & 0 & 0 & 0 & 0 & 0 & 0 & 0 & 100 \\
\hline Cook Is. & 0 & 0 & 0 & 0 & 0 & 0 & 100 & 0 & 0 & 0 & 0 \\
\hline Fiji & 0 & 25 & 0 & 0 & 0 & 0 & 0 & 0 & 0 & 0 & 0 \\
\hline Indonesia & 0 & 0 & 0 & 0 & 0 & 0 & 0 & 100 & 2310 & 100 & 200 \\
\hline Kosrae & 0 & 200 & 0 & 50 & 100 & 2050 & 100 & 50 & 110 & 70 & 210 \\
\hline Okinawa & 0 & 0 & 0 & 0 & 0 & 0 & 0 & 36 & 0 & 0 & 0 \\
\hline Palau & 54,154 & 40,498 & 24,079 & 17,097 & 2811 & 12,198 & 6973 & 11,804 & 31,249 & 32,023 & 41,369 \\
\hline P.N. Guinea & 0 & 0 & 0 & 0 & 50 & 4500 & 9000 & 0 & 0 & 30 & 350 \\
\hline Philippines & 0 & 200 & 0 & 200 & 0 & 0 & 0 & 24,925 & 0 & 2600 & 712 \\
\hline Pohnpei & 395 & 16,540 & 8660 & 1036 & 580 & 1090 & 1626 & 2006 & 4505 & 5693 & 20,577 \\
\hline Rota & 2007 & 2375 & 2429 & 1068 & 0 & 0 & 0 & 0 & 0 & 50 & 0 \\
\hline Saipan & 5283 & 6463 & 4711 & 650 & 0 & 0 & 0 & 0 & 0 & 0 & 0 \\
\hline Solomons & 3000 & 0 & 0 & 0 & 0 & 0 & 0 & 0 & 0 & 0 & 0 \\
\hline Thailand & 0 & 0 & 0 & 0 & 0 & 0 & 0 & 700 & 0 & 0 & 0 \\
\hline Tinian & 699 & 841 & 878 & 145 & 0 & 0 & 0 & 0 & 0 & 0 & 0 \\
\hline Tonga & 50 & 50 & 0 & 2400 & 12,500 & 11,600 & 0 & 0 & 0 & 0 & 0 \\
\hline Truk & 325 & 323 & 1247 & 3085 & 1530 & 4421 & 600 & 2730 & 3587 & 9870 & 12,286 \\
\hline Ulithi & 0 & 150 & 0 & 0 & 0 & 0 & 0 & 0 & 0 & 0 & 0 \\
\hline Vanuatu & 0 & 0 & 0 & 0 & 0 & 12 & 0 & 0 & 0 & 0 & 0 \\
\hline W. Samoa & 0 & 0 & 1850 & 8850 & 21,575 & 25,750 & 37,150 & 46,700 & 3400 & 1200 & 230 \\
\hline Yap & 14,674 & 33,685 & 11,916 & 0 & 0 & 0 & 0 & 0 & 0 & 0 & 475 \\
\hline Total & 80,727 & 102,079 & 56,495 & 38,061 & 39,346 & 82,933 & 66,149 & 90,556 & 45,386 & 51,636 & 76,509 \\
\hline
\end{tabular}

* Import figures for FY 1980 cover a 15-month period.

prompted the bat buyers on Guam and in the CNMI to increase imports from outside sources. Declines in flying fox populations and enactment of protective legislation in some areas led importers to seek additional sources of supply from as far away as Western Samoa and American Samoa. A ban on harvesting and export of bats on Yap in 1981 appears to have been largely effective.
Conversely, a ban on the use of firearms in the harvesting of bats in Palau has evidently had little salutary effect, since Palau has been the largest supplier of bats to Guam since imports began. With the restriction of flying fox exports from Samoa in recent years, imports to Guam from the Federated States of Micronesia, primarily Truk and Pohnpei, have increased markedly. These two states and

Table 4. Total number of flying foxes requested for import into Guam vs, total number actually imported, 1979-1989

\begin{tabular}{lrrrrrrrrrrr}
\hline & 1979 & 1980 & 1981 & 1982 & 1983 & 1984 & 1985 & 1986 & 1987 & 1988 & 1989 \\
\hline Requested & 80,727 & 102,079 & 56,495 & 38,061 & 39,346 & 82,933 & 66,149 & 90,556 & 45,386 & 51,636 & 76,509 \\
Imported & 24,621 & 29,554 & 15,250 & 10,793 & 12,895 & 16,258 & 10,084 & 13,448 & 9404 & 13,587 & 16,664 \\
\hline
\end{tabular}




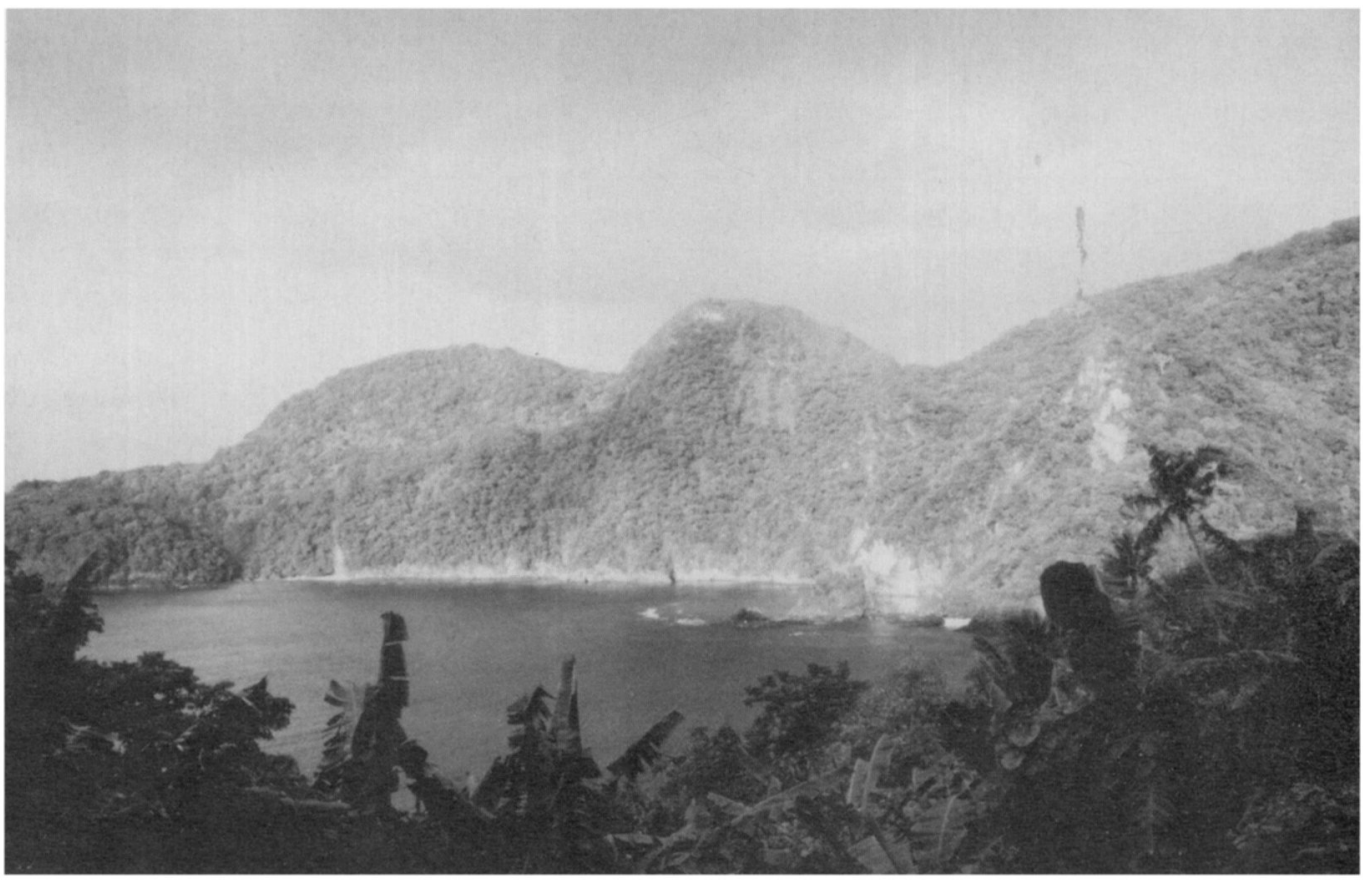

View of Tutuila, American Samoa (E. D. Pierson).

Palau are currently the major exporters to Guam.

The Guam Division of Aquatic and Wildlife Resources (DAWR) controls flying fox imports into Guam. Although import permits and certificates of origin are required and imports prohibited in contravention of wildlife laws of the country of origin, the DAWR has no authority to limit the number of animals imported. DAWR began keeping records on imports and requests for import in 1975 (Tables 2 and 3). These document the number of flying foxes both sought for import and actually shipped into Guam as well as the shifting nature of the trade in response to changes in availability throughout the region. As such, they are useful in identifying potential future export markets. Despite the 1987 listing of nine species on CITES Appendix II, imports into Guam have continued to increase since that year, itself a low-volume year due to a dramatic drop in exports from Western Samoa (Guam's major importer/retailer, importing primarily from Western Samoa, went out of business in that year). Wiles (pers. comm.), suspecting import figures for the late 1970 s-early 1980 s to be inflated due to having been partially based on extrapolations, believes 1989 to have been the highest import year on record, with a total import volume of almost 17,000 animals.

The difference between actual import figures and figures for animals requested for import (Table 4) reveals the full potential of the import trade based on demand and-it would seem-its limitations in terms of supply. While Wiles and Payne (1986) noted that requests are often inflated to respond opportunistically to supply, they can be used as an indication of demand: in 1986 alone, importers requested to import 90,556 animals, a full seven times the number actually imported13,448-during that year. Because Guam DAWR does not restrict the number of bats imported, the explanation for this difference is almost exclusively limited supply.

In the CNMI, where wildlife trade controls are apparently rudimentary and no records 
are maintained, there are no details on imports of flying foxes. However, Wiles (in litt.) has estimated that as many as 4000 flying foxes are imported into Saipan in the CNMI annually. Data compiled from air-freight documents indicating average imports into the CNMI of 3284 animals a year from 1986 to 1989 (D. Stinson, pers. comm.) substantiate this estimate. The total number of flying foxes imported into the CNMI and Guam was almost 21,000 in 1989 alone.

\section{CITES implementation problems- shortcomings in the US}

While Palau's status as the last remnant of the US Pacific Trust Territory has allowed for exports to Guam to bypass CITES requirements (as it is viewed as internal under CITES), several treaty implementation problems in Guam and the CNMI have precluded the 1987 CITES Appendix II listing from having any impact on international trade in these species. If they persist, these problems risk

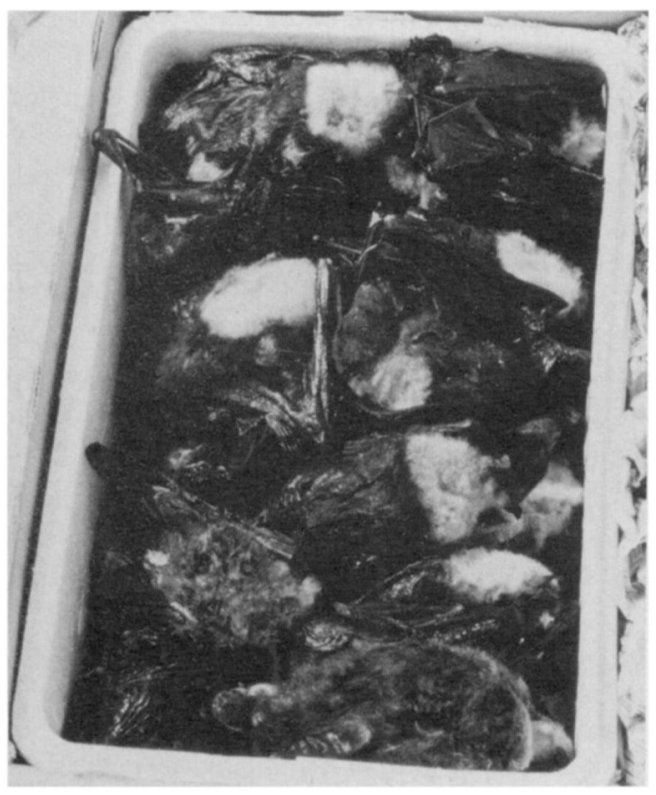

Frozen insular Pteropus tonganus and Samoan Pteropus samoensis flying foxes confiscated on entry into Guam (W. E. Rainey). having similar consequences for the recent Appendix I listing and require immediate resolution. As a special port for fish and wildlife under US federal wildlife regulations, Guam would be expected to have an inspector on site to monitor and control wildlife shipments. Unfortunately, however, the US Fish and Wildlife Service (FWS) has had no continuous enforcement presence in this part of the Pacific for several years. Officials on Guam have continued to enforce local legislation pertaining to flying fox imports, but where authority to carry out US treaty obligations is vested with the federal government, they can do little more. Imports of flying foxes have, therefore, continued unabated, despite statutory responsibilities on the part of the FWS to exercise control over them. Failure of the US authorities to monitor or control flying fox imports into the US left a single option for Pacific Island taxa-transfer to CITES Appendix I (Bräutigam, 1988). Fears that the absence of enforcement personnel on Guam might undermine the recent CITES listings as well prompted a recent decision by the FWS to detail an inspector to Guam for the remainder of this fiscal year (until 1 October 1990). While this is indeed an encouraging sign, the likelihood that permanent personnel will be assigned to the region to guarantee compliance with federal regulations and investigate violations, appears to depend largely on the federal appropriations process, which is now under way. The FWS had once again made no provision for this important post in its FY1991 budget. While effective enforcement of CITES has obvious implications for the species transferred to Appendix I, there must be equally concerted action with respect to the Appendix II species, which may become subject to trade pressure as a result of the Appendix I listing. Such action will be possible only through increased investment of federal resources.

\section{Other conservation needs-prospects for the future}

While there is clearly much progress to be made in improving trade controls in the US in 
order to ensure the long-term survival of flying foxes in the Pacific, it is also evident that more work will need to be done to assess levels of acceptable harvest for local use, and to ensure preservation of sufficient roosting and foraging habitat for their populations. This latter problem is an especially daunting one, as habitat destruction in Samoa and on other islands of the Pacific is accelerating. In Western Samoa, for example, government estimates predict a total loss of forest resources within 20 years. Clearings for agriculture and commercial harvest of rain-forest timber have already resulted in the loss of 80 per cent of the lowland rain forest in both Western and American Samoa.

Several initiatives to protect forest habitat have already been set in motion. In 1988, for example, the US Congress enacted legislation to establish a national park on American Samoa, thereby protecting 10,000 ha of rain forest and associated coral reef. In Western Samoa, with financial assistance from private donors, a 15,000-ha rain-forest area, Falealupo, has been established as a reserve, where hunting of flying foxes is completely prohibited. A similar agreement was concluded in January this year for another 10,000-ha rain forest on Savai'i, Tafua. In this case, funds have been raised in Sweden by the Swedish Society for the Conservation of Nature. WWF-Sweden is supporting a research project in Samoa that will be important for the development of a successful conservation strategy for flying foxes.

Unfortunately, the progress made through these activities has been sorely set back by the devastating effects of a typhoon that hit Western Samoa and American Samoa in early February. While conservationists are optimistic that the rain forest will recover, they are concerned that the already reduced flying fox populations may not be so resilient. Starvation and increased human predation may take an inordinate toll.

Additional projects and activities to address the conservation needs of Pacific Island flying foxes were the focus of a recent symposium hosted by Bat Conservation International in Hawaii in February, which was attended by representatives of a number of Pacific Island States, Papua New Guinea, the Philippines, and the United States as well as bat biologists and other conservationists. In addition to calling for resolution of the CITES enforcement problem, the conference recommended priorities for future research on flying foxes, such as surveys in Palau and the Federated States of Micronesia, the primary sources for bats imported into Guam in recent years, to evaluate the impact of harvest for trade, and the designation of protected areas essential to bat conservation. These recommendations will be incorporated in the Pteropus Action Plan now being developed by the Chiroptera Specialist Group of the IUCN Species Survival Commission.

\section{In conclusion}

As has been the case with numerous other economically important species approved for listing on CITES Appendix I, including, most recently, the African elephant Loxodonta africana, it is after the listing has come into effect that the most challenging work begins. Ensuring effective enforcement of trade prohibitions, monitoring trade shifts to other, less protected species, and identifying areas of flying fox habitat where human impact should be limited will require research, data analysis, public awareness, and policy work on the part of many individuals and institutions. To allow recent progress to lead to complacency about the conservation prospects for these species and the ecosystems dependent upon them would be a serious mistake.

\section{Acknowledgments}

We would like to thank Linda Hedlund, Swedish delegate to the Seventh Meeting of the Conference of the Parties to CITES, for her enthusiasm and commitment to flying fox conservation; Gary Wiles and the Guam Division of Aquatic and Wildlife Resources, but for whose data we would be unable to quantify levels of trade in flying foxes; and Charles Dane of the US Office of Scientific Authority, for his interest in flying foxes. The Center 
for Marine Conservation has provided generous financial support for the Trade Specialist Group's work on the flying fox trade. Paul Cox has catalysed conservation efforts in Western Samoa. Finally, we wish to thank Dixie Pierson and Bill Rainey for their indefatigable efforts on behalf of Pacific Island flying foxes and for their assistance and advice in the review of earlier drafts of this article.

\section{References}

Anon. 1976. Study of the fruit bat. In Guam Division of Aquatic and Wildlife Resources Annual Report FY 1976, pp.72-75. Department of Agriculture, Guam.

Anon. 1978. Study of the fruit bat. In Guam Division of Aquatic and Wildlife Resources Annual Report FY 1978, pp.111-117. Department of Agriculture, Guam.

Anderson, R.A. 1980. The current status, distribution and natural history of Marianas fruit bats. In Guam Division of Aquatic and Wildlife Resources Annual Report FY 1980, pp.245-303. Department of Agriculture, Guam.

Baker, H.G. and Harris, B.J. 1959. Bat-pollination of the silk-cotton tree, Ceiba pentandra (1.) Gaertn. (Sensu Lato), in Ghana. J. West Afr. Science Assoc. 5, 1-9.

Bräutigam, A. 1988. Flying Foxes in Danger. Species, 11, 11-12.

Charles-Dominique, P. 1986. Inter-relations between frugivorous vertebrates and pioneer plants: Cecropia, birds and bats in French Guyana. In Frugivores and Seed Dispersal (eds. A. Estrada and T.H. Fleming), pp.119-134. W. Junk, Dordrecht, Netherlands.

Cox, P.A. 1984. Chiropterophily and ornithophily in Freycinetia (Pandanaceae) in Samoa. Plant Syst. Evol. 144, 277-290.

Falanruw, M.V.C. 1988. On the Status, Reproductive Biology and Management of Fruit Bats of Yap. Micronesica, 21 (1-2), 39-51.

Fujita, M.S. and Tuttle, M.D. 1988. Economic importance of bat/plant interactions in paleotropical regions. Report to World Wildlife Fund, Washington, D.C.

Lemke, T.O. 1986. Marianas fruit bats near extinction. Bats, 3(1), 1-2.

Marshall, A.J. 1985. Old World phytophagous bats (Megachiroptera) and their food plants: a survey. Biol. J. Linn. Soc. 83, 351-369.

Musser, G.G., Koopman, K.F., and Califia, D. 1982. The Sulawesian Pteropus arquatus and P. argentatus are Acerodon celebensis; the Philippine P. leucotis is an Acerodon. J. Mamm. 63, 319-328.

Thomas, T., 1987. [Abstract]. Seed rains generated by pteropodid and phyllostomoid fruit bats. Bat Research News, 28 (3-4), 38.

Wheeler, M.E. 1979. Study of the fruit bat. In Guam Division of Aquatic and Wildlife Resources Annual Report FY 1979, pp.230-260. Department of Agriculture, Guam.

Wiles, G.J. 1981. The current status, distribution and natural history of Marianas fruit bats. In Guam Division of Aquatic and Wildlife Resources Annual Report FY 1981, pp.160-166. Department of Agriculture, Guam.

Wiles, G.J. 1982. The current status, distribution and natural history of Marianas fruit bats. In Guam Division of Aquatic and Wildlife Resources Annual Report FY 1982, pp.204-211. Department of Agriculture, Guam.

Wiles, G.J. 1983. The current status, distribution and natural history of Marianas fruit bats. In Guam Division of Aquatic and Wildife Resources Annual Report FY 1983, pp.157-173. Department of Agriculture, Guam.

Wiles, G.J. 1984. The current status, distribution and natural history of Marianas fruit bats. In Guam Division of Aquatic and Wildlife Resources Annual Report FY 1984, pp.151-157. Department of Agriculture, Guam.

Wiles, G.J. 1985. The current status, distribution and natural history of Marianas fruit bats. In Guam Division of Aquatic and Wildlife Resources Annual Report FY 1985, pp.112-123. Department of Agriculture, Guam.

Wiles, G.J. 1986. The current status, distribution and natural history of Marianas fruit bats. In Guam Division of Aquatic and Wildlife Resources Annual Report FY 1986, pp.111-121. Department of Agriculture, Guam.

Wiles, G.J. 1987. The current status, distribution and natural history of Marianas fruit bats. In Guam Division of Aquatic and Wildlife Resources Annual Report FY 1987. Department of Agriculture, Guam.

Wiles, G.J. 1988. The current status, distribution and natural history of Marianas fruit bats. In Guam Division of Aquatic and Wildlife Resources Annual Report FY 1988. Department of Agriculture, Guam.

Wiles, G.J. and N.H. Payne, 1986. The trade in fruit bats Pteropus spp. on Guam and other Pacific islands. Biol. Conserv. 38, 143-161.

Amie Bräutigam, Deputy Chairman, Species Survival Commission Trade Specialist Group of IUCN, the World Conservation Union, Center for Marine Conservation, 1725 DeSales Street, NW, Suite 500, Washington, DC 20036, USA.

Thomas Elmqvist, Department of Ecological Botany, Umea University, 90187 Umea, Sweden. 